\title{
Vergi/Ceza İhbarnamelerine Vergi Inceleme ve/veya Vergi Tekniği Raporlarının Eklenmemesinin İyi İdare ve Dosyaya Giriş Hakları Kapsamında Değerlendirilmesi
}

\section{Evaluation of Not Adding Tax Inspection and/or Tax Technique Reports to Tax/Penalty Notices within the Scope of Good Administration and Access to File Rights}

\author{
Ece Fatma Aslan*
}

\section{ARTICLE INFO \\ Submitted : 26.02.2021 \\ Revised : 10.04.2021 \\ Accepted : 21.05.2021 \\ Available : 30.06.2021 \\ iThenticate similarity score: $16 \%$ \\ JEL classification: K23, K34, K38 \\ Keywords: \\ Tax inspection report, Technical tax report, the Right to a fair trial, the Right of defence, the Right to good administration, the Right to access to file}

\begin{abstract}
A B S T R A C T
In practice, taxpayers receive tax /penalty reports that do not include tax inspection reports and technical tax reports. This application constitutes a breach of the rights of taxpayers to access documents and to their own files. As it's well known such rights are an integral part of the rights of defence and to a fair trial. This right shall be granted not only in judicial courses but also in administrative procedures. However, in Turkey, there are some landmark cases on the contrary which are victimizing taxpayers. Therefore, taxpayers need another alternative compared to commencing a lawsuit against the missing reports.

This study aims to find another alternative against such court decisions by examining local and EU laws and cases. Within this concept, It is suggested that making an application to the Ombudsman Institution maybe this alternative. In this way, taxpayers will be entitled to demand a warning letter against the application of the relevant tax administration and request an opinion for a change in legislation from the Ombudsman.
\end{abstract}

Cite this article as: Aslan, E.F. (2021). "Vergi/Ceza İhbarnamelerine Vergi İnceleme ve/veya Vergi Tekniği Raporlarının Eklenmemesinin İyi İdare ve Dosyaya Giriş Hakları Kapsamında Değerlendirilmesi", International Journal of Public Finance, 6(1), 115-136.

Arb. Av., PhD Student, Bursa Uludag University, Institute of Social Sciences, Department of Public Law, PhD Program, https://orcid.org/0000-0003-0910-639X, ecefatmaaslan@istanbul.av.tr 
Aslan, E.F. (2021). “Vergi/Ceza İhbarnamelerine Vergi İnceleme ve/veya Vergi Tekniği Raporlarının Eklenmemesinin İyi İdare ve Dosyaya Giriş Hakları Kapsamında Değerlendirilmesi", International Journal of Public Finance, 6(1), 115-136.

\begin{tabular}{|c|c|}
\hline MAKALE BİLGisi & $Z$ \\
\hline Gönderme: 26.02.2021 & \multirow{6}{*}{$\begin{array}{l}\text { Vergi inceleme raporu ve vergi tekniği raporlarının vergi/ceza } \\
\text { ihbarnamelerine eklenerek mükelleflere iletilmemesi adil yargılanma ve } \\
\text { savunma hakkının bir parçası olan "bilgi edinme ve dosyaya giriş hakkının" } \\
\text { ihlali niteliğindedir. Söz konusu hak sadece adli süreçlerde değil, "iyi } \\
\text { yönetim hakkı" kapsamında idari süreçlerde de ilgililere tanınmalıdır. } \\
\text { Fakat ülkemizde konuyla ilgili olarak aksi yönde verilen mahkeme kararları } \\
\text { mükelleflerin mağduriyetine yol açmaktadır. }\end{array}$} \\
\hline Düzeltme : 10.04.2021 & \\
\hline Kabul $\quad: 21.05 .2021$ & \\
\hline Yayın $\quad: 30.06 .2021$ & \\
\hline & \\
\hline JEL Kodu: & \\
\hline $\mathrm{K} 23, \mathrm{~K} 34, \mathrm{~K} 38$ & \multirow[b]{2}{*}{$\begin{array}{l}\text { Bu çalışmanın amacı mükelleflerin dava açtıklarında aksi yöndeki kararlar } \\
\text { sebebiyle haksız çıkma ihtimallerini ortadan kaldırmak için dava açmak } \\
\text { yerine başvurabilecekleri alternatif çözümlerin neler olabileceğini } \\
\text { tartışmaktır. Bu kapsamda öncelikle AB hukuku düzenlemeleri ve } \\
\text { kararlarıyla birlikte mevzuatımız ve içtihatlar incelenmiştir. Inceleme } \\
\text { sonucunda Kamu Denetçiliği Kurumu'na yapılacak bir başvurunun } \\
\text { alternatif bir çözüm yolu olabileceği kanaatine ulaşılmıştır. Bu çerçevede } \\
\text { mükelleflerin dava açmadan önce konuyu Kamu Denetçiliği Kurumuna } \\
\text { taşıyarak idarenin konuyla ilgili olarak ikaz edilmesini ve mevzuat } \\
\text { değişikliği önerisinde bulunulmasını talep etmelerinin mümkün olabileceği } \\
\text { değerlendirilmektedir. }\end{array}$} \\
\hline $\begin{array}{l}\text { Anahtar Kelimeler: } \\
\text { Vergi İnceleme Raporu, } \\
\text { Vergi Tekniği Raporu, } \\
\text { Adil Yargılanma Hakkı, } \\
\text { Savunma Hakkı, lyi } \\
\text { Yönetim Hakkı, Bilgi } \\
\text { Edinme Hakkı, } \\
\text { Dosyaya Giriş Hakkı }\end{array}$ & \\
\hline
\end{tabular}

\section{Giriş}

İçtihat hukukunda Avrupa İnsan Hakları Sözleşmesi'nin ${ }^{1}$ (AiHS) 6. maddesi kapsamında adil yargılanma hakkının (Yaltı, 2006: 81-82) ${ }^{2}$ sadece mahkemelerde ve yargı aşamasının bütününde tanınan bir hak olduğu görüşü hâkimdir. Buna göre idarenin yürüttüğü inceleme, araştırma, soruşturma ve denetim faaliyetleri gibi yarı yargısal süreçlerde, sonunda ilgililerine cezai yahut idari yaptırım uygulanacak olsa dahi, söz konusu hakka tam olarak riayet edilmesine gerek bulunmamaktadır. Bu algıya özellikle Avrupa İnsan Hakları Mahkemesi'nin (AiHM) 1996 tarihli Miailhe/ Fransa kararının neden olduğu görülmektedir (Turinay, 2014: 335 vd.).

Oysa ki vergi davaları ile vergi incelemeleri arasında doğrudan bir bağ olması nedeniyle adil yargılanma hakkı vergilendirme sürecinin başından itibaren her

1 İnsan Hakları ve Özgürlüklerinin Korunmasına İlişkin Avrupa Sözleşmesi (AiHS) 4 Kasım 1950'de Roma'da imzalanmış ve 3 Eylül 1953'te yürürlüğe girmiştir. AiHS 59 maddeden ve ek protokollerden oluşur. Türkiye 18 Mayıs 1954'te sözleşmeyi onaylamış ve 28 Ocak 1987'de de bireysel başvuru hakkını tanımıştır. Mahkemenin zorunlu yargı yetkisi ise 28 Ocak 1990'da kabul edilmiştir. AiHS, Avrupa Konseyi üyesi 47 devlet tarafından onaylanmıştır.

2 "Adil yargılanma hakkı sözleşmede kavram olarak tanımlanmamış bir haklar bütünüdür. Sayılan hak ve güvenceler bir bütün olarak adil yargılanmayı sağlamaya yönelmiştir. Adil yargılanma hakkı, adli mekanizmanın işleyiş ve organizasyonunda bireye bir dizi usuli güvence sağlayan bir haklar blokudur. (...) 6/1. Maddede adil yargılanma hakkının bazı unsurları açıkça, ancak tüketici olmayan biçimde belirtilmiştir: yargı yerinin tarafsız ve bağımsız ve yargılamanın adil ve aleni olması ve makul sürede yapılması gibi. Fıkranın saklı içeriği ise iHAM kararları ile somutlaşmaktadır. Bu çerçevede, adil yargılanma hakkı, mahkemeye başvurma hakkı, silahların eşitliği ilkesi, çelişmeli yargılama ilkesi ve susma hakkı gibi hak ve ilkeleri de içerir.6/2-3. Maddede ise ceza yargılamasında uyulması gereken asgari ilkeler sıralanır. Bunlar, masumiyet karinesine (6/2) ve sanık haklarına (6/3) ilişkindir." 
Aslan, E.F. (2021). "Vergi/Ceza İhbarnamelerine Vergi İnceleme ve/veya Vergi Tekniği Raporlarının Eklenmemesinin İyi İdare ve Dosyaya Giriş Hakları Kapsamında Değerlendirilmesi",

International Journal of Public Finance, 6(1), 115-136.

aşamasında gözetilmelidir. Nitekim AiHM'nin vergi süreçleriyle ilgili kararları incelendiğinde arama, inceleme, raporlama gibi idari aşamaların tamamında adil yargılanma hakkının gözetilmesi gerektiği görülmektedir (Yaltı, 2016: 54).

Ayrıca çalışmamızın ilerleyen bölümlerinde detaylı şekilde açıklanacağı üzere, vergi inceleme raporu ve vergi tekniği raporlarının vergi/ceza ihbarnamelerine eklenerek mükelleflere iletilmemesi AiHS madde 6(3)(a) ve (b) uyarınca adil yargılanma ve savunma hakkının bir parçası olan "bilgi edinme ve dosyaya giriş hakkının", bir diğer ifade ile "kendisine karşı yöneltilen suçlamanın niteliği ve sebebinden en kısa sürede haberdar olmak" ve "savunmasını hazırlamak için gerekli kolaylıklara sahip olmak" hakkının ihlali niteliğindedir. Zira AB hukuku kapsamında söz konusu hak sadece adli süreçlerde değil, "iyi yönetim hakkı" kapsamında idari süreçlerde de ilgililere tanınması gereken bir haktır ${ }^{3}$ (Yaltı, 2006: 82- 100). Konuyla ilgili olarak Türkiye'deki yüksek mahkemelerce verilmiş kararlar mükelleflerin mağduriyetine yol açmaktadır. Söz konusu hak ihlalleri nedeniyle ortaya çıkan mağduriyetlerin engellenmesi için Kamu Denetçiliği Kurumuna başvuruda bulunularak Kurum tarafından vergi idaresinin konuyla ilgili ikaz edilmesi ve mevzuat değişikliği talep edilmesi yönteminin denenebileceği düşünülmektedir.

\section{Vergi/Ceza İhbarnamelerine Vergi İnceleme ve Vergi Tekniği Raporlarının Eklenmemesi ile ilgili Yüksek Mahkeme Kararları}

\subsection{Danıştay VDDK Kararı}

Danıştay Vergi Dava Daireleri Kurulu (VDDK) 03.07.2019 tarihli, E.2019/559, K. 2019/437 sayılı kararında (Saban, 2020: 379), AiHM'nin 1996 tarihli Miailhe/ Fransa kararına (Yaltı, 2006: 128-130) atıfla, adil yargılanma hakkı değerlendirilirken sadece

3 AïHS'nin 6. maddesi lafzına göre adil yargılanma hakkının kapsamı medeni hak ve yükümlülüklerden doğan uyuşmazlıklar ile bir kişiye cezai alanda suçlamada bulunulması ile sınırlıdır. Bu doğrultuda geçmişte doktrinde hakkının kapsamının özel hukuk ve ceza hukukundan doğan davalar ile sınırlı olduğu, kamu ve/ veya idare hukukuna genişletilemeyeceği yönünde tartışmalar yapıldığı görülmektedir. Özellikle 2000'li yılların başına kadar AiHM tarafından da idarenin takdir yetkisinden doğan uygulamaların ve vergi ödevi gibi vatandaşlık görevlerinin adil yargılanma hakkı kapsamı dışında tutulduğu görülmektedir. Fakat cezai alanda suçlanma kavramı kapsamına disiplin cezalarının ve kabahatlerin de dâhil edildiği ve bunların da adil yargılanma hakkı kapsamında değerlendirildiği anlaşılmaktadır. Belirtilen nedenlerle AïM tarafından vergi asıllarına ilişkin uyuşmazlıklar adil yargılanma hakkı kapsamında değerlendirilmemektedir (Bkz. Ferrazzini v. Italy, 12.07.2001, Bruno v Sweden, 28.08.2001). Fakat hukuka aykırı olarak uygulanan vergiler nedeniyle ortaya çıkan zararların giderilmesi için açılan maddi, manevi tazminat davaları (Bkz. Editions Periscope v. France, 26.03.1992; Terem Ltd, Chechetkin and Olius v. Ukraine, 18.01.2006) adil yargılanma hakkı kapsamında değerlendirilmektedir. Benzer şekilde vergi kabahatleri ve suçları ile ilgili olan uyuşmazlıklarda da adil yargılanma hakkına riayet edildiği görülmektedir (Bkz. Bendenoun v. France, 24.02.1994, Janosevic v. Sweden, 23.07.2002). Avrupa Birliği (AB) Hukukunda adil yargılanma hakkının idari süreçleri kapsamına almaması sebebiyle ortaya çıkan eksikliği gidermek amacıyla çalışmanın ilerleyen bölümlerinde daha detaylı şekilde incelenecek olan "iyi yönetim hakkının" ortaya çıkarıldığı ve 2009 yılında Lizbon Anlaşması ile söz konusu hakkın birlik hukuku içerisinde bağlayıcı hale getirildiği düşünülmektedir. 
Aslan, E.F. (2021). "Vergi/Ceza İhbarnamelerine Vergi İnceleme ve/veya Vergi Tekniği Raporlarının Eklenmemesinin İyi İdare ve Dosyaya Giriş Hakları Kapsamında Değerlendirilmesi", International Journal of Public Finance, 6(1), 115-136.

belirli bir hadiseye yahut usule değil, idari ve adli tüm aşamalara bakılarak kümülatif analiz yapılması gerektiğini ve idari aşamadaki şekli kusurun (vergi/ceza ihbarnamesine vergi inceleme raporu eklenmemesinin), ilk derece mahkemesi tarafından rapor talep edilip davacıya tebliğ edilerek adli aşamada giderilebileceği gerekçesi ile adil yargılanma hakkının ihlal edilmiş sayılmayacağını belirtmiştir ${ }^{4}$ (Yavaşlar vd., 2018: 265). Söz konusu kararda adil yargılanmanın idare tarafından değil mahkeme tarafından gözetilecek bir hak olduğu vurgulanarak, 213 sayılı Vergi Usul Kanununun (VUK) 35. maddesinin son fıkrasına aykırı şekilde vergi inceleme raporlarının "vergi/ceza ihbarnameleri" ile birlikte mükelleflere tebliğ edilmemesinin söz konusu hakkın ihlali anlamına gelmeyeceği ifade edilmiştir. Keza Danıştay VDDK'nın 10.02.2016 tarihli ve E.2016/82, K. 2016/83 sayılı kararı ile Danıştay 3. Dairesi'nin 26.09.2017 tarihli, E. 2016/ 2949, K. 2017/6117 sayılı kararı da aynı yöndedir (Topçu, 2016: 336).

Oysaki yine Danıştay VDDK, yukarıda belirtilen kararlarla çelişkili olarak, 2014 senesinde vergi tekniği raporlarının "vergi/ceza ihbarnamelerine" eklenmemesinin savunma hakkının ihlali olarak değerlendirilmesi gerektiğini belirten başka bir karar vermiştir. Danıştay Vergi Dava Daireleri Kurulu'nun bahsi geçen 18.06.2014 tarihli ve E.2014/304, K.2014/563 sayılı kararında, sahte belge düzenlediği iddia edilen mükellef hakkında düzenlenen vergi inceleme raporu ve vergi/ceza ihbarnamelerinin dayanağı olan vergi tekniği raporunun, mükellefe dava açmadan önce tebliğ edilmemesi ve mükellefin dava açmadan önce dosyaya giriş taleplerinin de ilgili idare tarafından kabul edilmemiş olmasının, (söz konusu rapor dava açıldıktan sonra mahkemeye sunulmuş olsa bile) davacı mükellefin hangi "suç ile isnad edildiğini öğrenme ve savunma hakkını" ihlal ettiğine karar vermiştir" Nitekim Danıştay 7. Dairesi'nin 25.05.2016 tarihli, E. 2016/2220, K. 2016/4758 sayılı kararı da aynı yöndedir (Topçu, 2016: 336).

4 Aksi yönde bir karar için bkz. Danıştay 9. Dairesinin, 05.11.2009 tarihli, E. 2008/3530, K. 2009/3998 sayılı kararı. "Danıştay kararlarına göre tarhiyatın dayanağı inceleme raporunun ihbarnameye eklenmesinin ihbarnamenin hukuken geçerli olmasının ön koşulu olduğu, bu durumun esasa etkili ihbarnameyi hükümsüz kılacak nitelikte bir usul hatası olduğu sonucuna varıldığından dava konusu cezalı tarhiyatta isabet görülmediği..."

5 "Petrol ürünleri imalat ve ticari faaliyetinde bulunan davacı hakkında, kaçak akaryakıt satışı ve komisyon karşılığı sahte fatura düzenleme işiyle uğraştığı yolunda düzenlenen 17.6.2011 günlü ve VDENR-2011-1273/60 sayılı Vergi Tekniği Raporu'na göre düzenlenen vergi inceleme raporları uyarınca yapılan cezalı vergilendirmenin kaldırılması istemiyle dava açılmıştır.

incelenen dosyada, davacıya anılan vergi tekniği raporuna atıfla düzenlenen vergi inceleme raporlarının tebliğ edildiği, ancak tarh nedenini, matrahın bulunuş yöntemini ve tarhiyatın dayanağına ilişkin bilgi ve belgelerin gösterildiği davacı hakkında düzenlenmiş vergi tekniği raporunun tebliğ edilmediği anlaşılmaktadır.

Vergi Usul Kanununun 34'üncü maddesinin, ikmalen ve resen tarh edilen vergilerin ilgilisine ihbarnameyle tebliğ edilmesine ilişkin düzenlemesine bağlı olarak, izleyen 35'inci maddesinin ikinci fıkrasında varsa takdir komisyonu kararı veya inceleme raporunun birer suretinin ihbarnameye eklenmesini öngören düzenlemesi, talep veya dava hakkının gereği gibi kullanılmasını amaçlamaktadır. Buradan, mükelleflerin uzlaşma, dava açma ve savunma gibi yasal haklarını kullanabilmeleri için tarhiyatın dayanağı olan ve tarhiyatın yapılma nedeniyle matrah farkının tespitine ilişkin hesaplamaların nasıl yapıldığına dair açıklamaları içeren takdir komisyonu kararının, vergi inceleme raporunun ve tarhiyata dayanak alınan mükellef adına düzenlenmiş vergi tekniği raporunun ihbarnameye eklenmesi gerekmektedir. 
Aslan, E.F. (2021). "Vergi/Ceza İhbarnamelerine Vergi İnceleme ve/veya Vergi Tekniği Raporlarının Eklenmemesinin İyi İdare ve Dosyaya Giriş Hakları Kapsamında Değerlendirilmesi", International Journal of Public Finance, 6(1), 115-136.

\subsection{Anayasa Mahkemesi Kararı}

Danıştay VDDK'nın 2019 yılında vermiş olduğu karara benzer şekilde Anayasa Mahkemesi de (AYM) 2016/12198 başvuru numaralı kararında, vergi idaresinin sahte belge kullanılması nedeniyle kestiği vergi cezasının dayanağını teşkil eden "vergi tekniği raporunun" ilgilisine dava açılmadan önce tebliğ edilmemesinin adil yargılanma hakkını ihlal etmeyeceğine karar verilmiştir.

Bilindiği gibi VUK kapsamında yapılan vergi incelemeleri neticesinde düzenlenen vergi inceleme raporlarına ek olarak vergi tekniği raporları ${ }^{6}$ hazırlanmaktadır. Uygulamada sahte belge düzenleyen mükellefler hakkında hazırlanan vergi tekniği raporlarının, bu belgeleri kullanan diğer mükellefler hakkında yapılan incelemeler neticesinde oluşturulacak vergi inceleme raporlarına, sahte belge düzenleyen mükellefin mahremiyet hakkının ${ }^{7}$ korunması bahanesiyle ek yapılmadığı, söz konusu vergi tekniği raporunda, mükellefin mal veya hizmet alış ve satışı yaptığı diğer mükelleflerin ayrıntılı bilgilerine de yer verildiği gerekçesi ile raporun diğer bir mükellefe tebliğ edilmesinin vergi mahremiyeti ihlaline yol açacağının ileri sürüldüğü ve konunun yüksek yargıya taşınan bir hukuki problem haline geldiği anlaşıımaktadır.

Vergi Denetim Kurulu Yönetmeliğinin 57(4)'üncü maddesine göre "Sahte belge düzenleme fiili dolayısıyla düzenlenen Vergi Tekniği Raporunun başka bir mükellefin sahte belge kullandığına ilişkin tespitler içermesi durumunda, söz konusu Vergi Tekniği Raporu,_sahte belge kullanan mükellef nezdinde düzenlenecek vergi inceleme

Bu durumda, davacının hangi suç ile isnad edildiğini öğrenme ve bu duruma göre savunma yapma hakkı elinden alındığı gibi kendisine ait bilgilerin verilmemesi, 213 s. Kanunun "Vergi Mahremiyeti" başlıklı 5'inci maddesi kapsamında da değerlendirilemeyeceğinden, sadece vergi ve ceza ihbarnamesiyle vergi inceleme raporu tebliğ edilmek suretiyle, işlemlerin dayanağı mükellef adına düzenlenen vergi tekniği raporunun davacıya tebliğ edilmemesi davacı hakkında tesis edilen işlemi hükümsüz kılacak nitelikte esasa etkili bir şekil hatası olduğu halde, davacının bu konudaki iddiaları gözetilmeden davanın esası incelenerek verilen karar hukuka uygun görülmediğinden bozulması gerekmiştir.

Açıklanan nedenlerle, Ankara 3. Vergi Mahkemesi, 7.3.2014 günlü ve E:2014/576, K:2014/304 sayılı ısrar kararının bozulmasına, yeniden verilecek kararda karşılanacağından yargılama giderleri hakkında hüküm kurulmasına gerek bulunmadığına, 18.06.2014 tarihinde oyçokluğuyla karar verildi."

6 RG sayı 28101, 31.10.2011, Vergi Denetim Kurulu Yönetmeliği'nin 57/3 maddesinde Vergi Tekniği Raporunun hangi durumlarda düzenleneceği belirtilmiştir. Buna göre, "Yürütülmekte olan incelemelerde birden fazla mükellefi veya vergi türünü ya da aynı mükellefin birden fazla vergilendirme dönemini kapsayan eleştiri konusu yapılabilecek hususların tespit edilmesi halinde, konunun tek bir raporda ifade edilebilmesi amacıyla Vergi Tekniği Raporu düzenlenebilir. Bu raporlar, sonrasında düzenlenecek vergi inceleme raporlarının ekini oluşturur."

7 Vergi mahremiyeti VUK'nun 5'inci maddesi ile mükelleflere tanınan bir haktır. Söz konusu madde şu şekildedir: "Aşağıda yazılı kimseler görevleri dolayısiyle, mükellefin ve mükellefle ilgili kimselerin şahıslarına, muamele ve hesap durumlarına, işlerine, işletmelerine, servetlerine veya mesleklerine mütaallik olmak üzere öğrendikleri sırları veya gizli kalması lazımgelen diğer hususları ifşa edemezler ve kendilerinin veya üçüncü şahısların nef'ine kullanamazlar;

1. Vergi muameleleri ve incelemeleri ile uğraşan memurlar;

2. Vergi mahkemeleri, bölge idare mahkemeleri ve Danıştayda görevli olanlar;

3. Vergi kanunlarına göre kurulan komisyonlara iştirak edenler;

4. Vergi işlerinde kullanılan bilirkişiler." 
Aslan, E.F. (2021). "Vergi/Ceza İhbarnamelerine Vergi İnceleme ve/veya Vergi Tekniği Raporlarının Eklenmemesinin İyi İdare ve Dosyaya Giriş Hakları Kapsamında Değerlendirilmesi", International Journal of Public Finance, 6(1), 115-136.

raporlarına ek yapılmaz. Ancak, sahte belge kullanma fiili nedeniyle düzenlenecek vergi inceleme raporlarında, sahte belge düzenleyicisinin bu fiili işlediğinin tespitine dair Vergi Tekniği Raporunda yer alan bilgi, belge ve değerlendirmelere ayrıntılı olarak yer verilir."

Yönetmelik düzenlemesi nedeniyle sahte belge düzenleyenler hakkında oluşturulan Vergi Tekniği Raporlarının (VTR) bu belgeleri kullananlar için düzenlenecek Vergi Inceleme Raporlarına (VIR) ek yapılma imkânı bulunmamaktadır. Fakat ilgili Yönetmelik hükmüne göre düzenlenecek ViR'lerde, anılan VTR'lerde yer alan bilgi, belge ve değerlendirmelere ayrıntılı bir şekilde yer verilmesi gerekmektedir. Uygulamada ise, yönetmelik hükmünün aksine, ViR'lerde söz konusu VTR'lerin içeriğine yeterince detaylı şekilde yer verilmediği ve uyuşmazlıkların tam da bu sebeple ortaya çıktığı görülmektedir ${ }^{8}$ (Baykara, 2014: 65-66).

Anayasa Mahkemesi'nin yukarıda belirtilen kararına konu olan olayda da ilgili mükellefe VUK m. 359(2) uyarınca tedarikçisinin düzenlediği sahte belgeyi bilmeden kullanma suçu isnad edildiği halde, tedarikçi şirket hakkında oluşturulan VTR'nin mükellefle ilgili bölümlerinin vergi ceza ihbarnamesi ile birlikte tarafına gönderilmediği, söz konusu VTR'den de ihbarnamede sadece birkaç cümle ile bahsedildiği iddia edilmiştir.

Mükellefin yapılan işleme karşı açtığı davada mahkemenin nihai kararını vermesinden 3 gün önce VTR ilgili vergi idaresi tarafından dosyaya sunulmuştur. 3 gün gibi kısa bir süre içerisinde davacının VTR'yi görüp hakkında görüşlerini mahkemeye sunma imkânı olmamıştır. Fakat Mahkeme sahte belge kullanıldığı yönünde oluşturduğu nihai kararında VTR içeriğinden bahsetmiştir.

Bunun üzerine davacı ilk derece kararı aleyhine Bölge İdare Mahkemesinde (BiM) istinaf talebinde bulunmuştur. Davacı istinaf dilekçesinde nihai kararla ilgili yeni bir husus belirtmeksizin, VTR'nin kendisine gösterilmediğini ifade etmiş ve ilk derece mahkemesi önünde ileri sürdüğü tüm iddia ve savunmalarını tekrar etmiştir. Yargılama sonunda BiM davacıyı haksız görerek ilk derece vergi mahkemesi kararını onamıştır. BiM kararı üzerine konu 2577 sayılı İdari Yargılama Usulü Kanunu (IYUK) m. 46 ile belirtilen temyiz sınırının altında kaldığı için Anayasa Mahkemesi önüne bireysel başvuru yolu ${ }^{9}$ ile gelmiştir.

8 "Sahte belge kullanma nedeniyle mükellef veya tüzel kişilerinin yetkilileri hakkında açılan ceza davalarında da VTR sorunu bulunmaktadır. Öncelikle, vergi suçu raporu C. Savcılığına gönderilirken, bu rapora VTR'lerin de eklenmesi gerekirken bu yapılmamaktadır. C. Savcılığı aşamasında bilirkişi incelemesi yapılabilir ve çoğunlukla da yapılmaktadır. Bu durumda bilirkişiler, VTR'leri görmeden rapor yazmakta, Savcılık da VTR'leri görmeden, yani eksik soruşturma sonucu dava açmaktadır. Bu durumda, mahkeme CMK 174'üncü madde gereği "iddianamenin iadesi" kurumunu işletebilir, ancak şimdiye kadar bunu yapan mahkemeye rastlamadık. Mahkeme genellikle VTR'leri istemekte ve doğal olarak Maliye bu raporları ibraz etmektedir. Ancak VTR'lerin sağlanması üç-beş celse sürmektedir. Zamanaşımı süresi 5, uzamış zamanaşımı da 7,5 yılken birçok dava sırf VTR'ler temin edilemediği için zamanaşımına uğramaktaydı. Görüldügü gibi VTR'nin elde edilmesi ceza mahkemesinde de sorundur."

9 Bkz. https://www.anayasa.gov.tr/tr/mahkeme/gorev-ve-yetkileri/bireysel-basvuru/ (16.02.2021). Anayasa'da temel haklarla ilgili "evrensel ölçütlere" atıf yapan değişikliklerin son halkasını ise, 2010 
Aslan, E.F. (2021). "Vergi/Ceza İhbarnamelerine Vergi İnceleme ve/veya Vergi Tekniği Raporlarının Eklenmemesinin İyi İdare ve Dosyaya Giriş Hakları Kapsamında Değerlendirilmesi", International Journal of Public Finance, 6(1), 115-136.

AYM kararında VTR'nin davacıya tebliğ edilmemesinin adil yargılanma hakkını ihlal etmediği ifade edilmiştir. Zira karara göre içeriğinde gizli nitelikli ticari sırlar bulunan VTR'nin davacıya tebliğ edilmemesinin sebebi üçüncü kişi konumundaki mükellefin vergi mahremiyetinin korunmasıdır. Ayrıca söz konusu VTR'nin ilk derece mahkemesine sunulmuş ve bu mahkemenin verdiği nihai kararda detaylıca ele alınmış olması mükellefin savunma hakkının sınırlanmasını dengeleyen bir husus olarak değerlendirilmiştir. Yine aynı kararda benzer durumlarda ilgili belgelerin başvurucular tarafından bilinmesinde sakınca görülen kısımlarının karartılarak belgelerin kendilerine verilmesinin ya da mahkeme kaleminde inceleme fırsatının sunulmasının diğer telafi edici imkânlar olarak değerlendirilebileceği ifade edilmiştir.

AYM kararında VTR içeriğinin vergi mahkemesinin kararında teferruatlı biçimde ele alındığı belirtilmiştir. Dolayısıyla davacının raporun içeriği hakkında bilgi sahibi olmadığı iddia edilemez. Ayrıca davacının ilgili kararda yer alan tespitlere karşı iddialarını istinaf aşamasında ileri sürme imkânı olduğu halde bunu yapmadığı; davacının istinaf başvurusunda yalnızca vergi mahkemesindeki iddialarını tekrarlayıp yeni bir şey söylemediği için kusurlu olduğu ifade edilmiştir. Sonuç olarak AYM kararına göre yargılamadaki bir eksik yine yargılama süreci içinde telafi edildiği müddetçe adil yargılanma hakkı ihlal edilmiş olmayacaktır. Önemli olan eksikliğin bir bütün olarak yargılamanın hakkaniyetini etkilemesidir.

Çalışmamızın ilerleyen bölümlerinde daha detaylı şekilde açıklayacağımız üzere adil yargılanma ve savunma hakkı, sadece yargılama aşamasında değil aynı zamanda iyi yönetim ilkeleri gereği tüm idari süreçlerde de dikkate alınması gereken bir haktır. Zira aleyhine idari işlem yapılan kişilerin idari süreçler içerisinde kullanabilecekleri pişmanlık ${ }^{10}$, taahhüt ${ }^{11}$, uzlaşma, indirim vb. farklı hakları olabilmektedir. Vergi hukukunda da mükelleflerin yargıya gitmeden önce uzlaşma veya indirim talep etme hakları bulunmaktadır. Mükelleflerin VTR içeriğinden haberdar olmadan ve neyle

yılında 148'inci maddede yapılan Anayasa değişikliğiyle Anayasa Mahkemesine bireysel başvuru yolunun açılması oluşturmuştur. Bireysel başvurunun uygulamaya geçirilmesiyle, kamu gücünü kullanan kişi ve kurumların sebep olduğu hak ihlallerine karşı 23 Eylül 2012 tarihinden itibaren anayasal yargı denetimi başlatılmıştır.

10 Örneğin rekabet hukukunda pişmanlık müessesesi bulunmaktadır. Pişmanlık uygulamasının sınırları 15.02.2009 tarihli, 27142 sayılı Resmî Gazete'de yayınlanarak yürürlüğe giren “Kartellerin Ortaya Çıkarılması Amacıyla Aktif İşbirliği Yapılmasına Dair Yönetmelik" ile çizilmiştir. Söz konusu Yönetmeliğin amacı, "4054 sayılı Rekabetin Korunması Hakkında Kanunun 4'üncü maddesinde yasaklanmış olan kartellerin ortaya çıkarılması amacıyla Rekabet Kurumuyla aktif işbirliği yapan teşebbüsler ile teşebbüs yöneticileri ve çalışanlarına, aynı Kanunun 16 ncı maddesinde belirtilen para cezalarının verilmemesine veya verilecek cezalarda indirim yapılmasına ilişkin usul ve esasları düzenlemektir."

${ }^{11} 4054$ sayılı Rekabetin Korunması Hakkında Kanun'un 43. maddesine 16.06.2020 tarihinde 7246 sayılı Kanun'un 9'uncu maddesi ile yapılan değişiklikle taahhüt mekanizması getirilmiştir. Buna göre "yürütülmekte olan bir önaraştırma ya da soruşturma sürecinde 4'üncü veya 6'ncı madde kapsamında ortaya çıkan rekabet sorunlarının giderilmesine yönelik olarak ilgili teşebbüs ya da teşebbüs birliklerince taahhüt sunulabilir. Kurul söz konusu taahhütler yoluyla rekabet sorunlarının giderilebileceğine kanaat getirirse bu taahhütleri ilgili teşebbüs ya da teşebbüs birlikleri açısından bağlayıcı hale getirerek soruşturma açılmamasına veya açılmış bulunan soruşturmaya son verilmesine karar verebilir." 
Aslan, E.F. (2021). "Vergi/Ceza İhbarnamelerine Vergi İnceleme ve/veya Vergi Tekniği Raporlarının Eklenmemesinin İyi İdare ve Dosyaya Giriş Hakları Kapsamında Değerlendirilmesi", International Journal of Public Finance, 6(1), 115-136.

suçlandığını bilmeden diğer idari haklarını kullanmak konusunda bir seçim yapmaları imkânsızdır. Dolayısıyla, VTR'deki iddiaların öğrenilmesi yargı aşamasından önce mükellef haklarının kullanabilmesi açısından zaruri görülmektedir ${ }^{12}$ (Baykara, 2014: 63).

Ayrıca her ne kadar AYM kararına konu spesifik vakıa bakımından istinaf yolu açık olsa da diğer her durumda istinaf imkânı bulunmayabilecektir. Zira bilindiği üzere 2021 itibarıyla 7000 TL'nin altında olan vergi mahkemesi kararları iYUK m. 45'te belirtilen eşiğin altında kaldığı için istinafa gitmeksizin kesinleşmektedir. Dolayısıyla AYM konusu olayda dava istinaf sınırının altında kaldığı için ilk derece kararından sonra kesinleşmiş olsa idi, AYM'nin yine benzer yönde bir karar verip vermeyeceği merak konusu olmaktadır. Zira kararda adil yargılanma hakkının "yargılamanın bütünü" gözetilerek ele alınması gerektiği ifade edilmiştir. Fakat ilk derece mahkemelerinde kesinleşen kararlar bakımından istinafta telafi edilemeyecek bir durum ortaya çıkmaktadır. Bu noktada adil yargılanma hakkının yargılamanın bütününde değil, "her bir aşamasında" dikkate alınacağının kabul edilmesi daha doğru olacaktır (Ergin, 2020).

\section{Savunma ve Adil Yargılanma Hakkı}

\subsection{Genel Olarak}

Adil yargılanma hakkı Türk hukukunda 2709 sayılı Türkiye Cumhuriyeti Anayasası'nın 36. maddesi kapsamında değerlendirilmektedir. Madde metninde herkesin meşru vasıta ve yollardan faydalanmak suretiyle yargı mercileri önünde davacı veya davalı olarak iddia ve savunma ile adil yargılanma hakkına sahip olduğu belirtilmekte fakat bu hakkın ne olduğu ve kapsamı hakkında bilgi verilmemektedir.

1982 Anayasası'nın 36'ıncı maddesine, 03.10.2001 tarihinde 4709 sayılı Kanun'un 14. maddesi ile yapılan değişiklik ile "savunma" ibaresinden sonra gelmek üzere "ile adil yargılanma" ibaresi eklenmiştir. Belirtilen Anayasa değişikliğinin genel gerekçesinde $A B^{\prime}$ ne tam üyelik sürecinde gerekli yasal düzenlemelerin yapılması ile çağdaş demokratik standartlara ve evrensel normlara uygun insan haklarının ve hukukun üstünlüğünün öne çıkarılmasının amaçlandığı görülmektedir. Madde gerekçesinde ise, AiHS'nin 6. maddesine uygun olarak adil yargılanma hakkının sağlanmasının istendiği ifade edilmiştir.

Yine Anayasa'da 07.05.2004 tarihli ve 5170 sayılı Kanun ile 90'ıncı maddede yapılan değişiklik uyarınca iç-dış hukuk çatışmasında $A B^{\prime}$ ye uyum için Milletlerarası Anlaşmaların esas alınması kabul edilmiştir. 2004 yılının Mayıs ayında yapılan değişikliklerin genel gerekçesi olarak da AiHS'e ve evrensel olarak kabul görmüş temel

12 “VTR'nin en geç ihbarname ekinde mükellefe tebliği hukukun gereğidir. İşlemin asıl sebebini içeren VTR'nin dava aşamasında mahkemeye ibrazı, özellikle uzlaşma imkânı olan hallerde, tarh aşamasındaki mükellef haklarını geri getirmeyecektir. Verginin tarhı aşamasında mükellefin dava açmak, bazı durumlarda uzlaşmaya başvurmak veya en azından VUK 376. md. ye göre cezalarda indirim hakkından birini seçme imkânı mevcuttur. Oysa dava açmak için haklı olmak yetmez. Gerekli savunma araçlarına da sahip olmak gerekir. VTR'nin ihbarnameye eklenmemesi, sayılan üç haktan birini seçme imkânını ortadan kaldırmaktadır." 
Aslan, E.F. (2021). "Vergi/Ceza İhbarnamelerine Vergi İnceleme ve/veya Vergi Tekniği Raporlarının Eklenmemesinin İyi İdare ve Dosyaya Giriş Hakları Kapsamında Değerlendirilmesi", International Journal of Public Finance, 6(1), 115-136.

hak ve hürriyetler ile bu konuda $A B$ tarafından kabul edilmiş standartlara ulaşılması olarak gösterilmiştir ${ }^{13}$ (Gerek \& Aydın, 2004: 226).

\subsection{AB Hukukunda İyi Yönetim kapsamında Bilgi Edinme ve Dosyaya Giriş Hakkı}

AB hukukunda "dosyaya erişim hakkı" kavramı 1990'ların sonlarında ilk kez yüksek mahkemelerin (Avrupa Birliği Adalet Divanı ve Genel Mahkeme) rekabet hukukuna ilişkin ilişkin içtihatları ile ortaya çıkmış (Khan \& Kerse, 2012: 214) ve daha sonra da gümrük hukuku ${ }^{14}$ gibi idare hukukunun diğer alanlarına da genişlemiş bir kavramdır. Hali hazırda $A B$ rekabet hukukunda söz konusu hak 1/2003 sayılı Konsey Tüzüğünün 27(2) maddesi ${ }^{15}$ ile korunmaktadır. Genel Mahkeme'ye göre dosyaya erişim hakkı, savunma hakkının ayrılmaz bir parçasıdır (Tridimas, 2017: 398) ve dinlenilme hakkı kapsamında değerlendirilmektedir ${ }^{16}$. Günümüzde dosyaya erişim hakkı iyi yönetim hakkı ${ }^{17}$ kapsamı dâhilinde (Güzel \& Odyakmaz, 2017: 13-14); AB Temel Haklar

13 TBMM Tutanak Dergisi, Dönem: 22, Cilt: 48, Yasama Yılı: 2, 83. Birleşim, "Bir taraftan hayat hakkının, demokratik toplumun temel değeri olduğunu ve ölüm cezasının kaldırılmasının, bu hakkın korunması ve tüm insanların doğuştan gelen onurunun bütünüyle ve bu tanınması için elzem olduğunu vurgulayan ve ülkemizce de imzalanan Insan Haklarını ve Temel Özgürlükleri Koruma Avrupa Sözleşmesi'ne ek 13 nolu protokol gereğince ölüm cezasının kaldırılmış olması; diğer yandan dünyada, gelişen yeni demokratik açılımlara uyum sağlanması açılıma uygun bir şekilde temel hak ve hürriyetlerin, evrensel düzeyde kabul edilmiş standart ve normlar ile Avrupa Birliği kriterleri seviyesine çıkarılması amacıyla kanunlarımızda düzenlemeler yapılması ihtiyacı temel yasamı olan Anayasa'da da değişiklikler yapma zorunluluğu doğurmuştur".

14 Judgment of the Court of First Instance (GC) of 19 February 1998, T-42/96, Eyckeler and Malt AG v. Commission.

15 (EC) No 1/2003 sayılı, 16 Aralık 2002 tarihli Anlaşmanın 81 ve 82'inci maddelerinde belirtilen rekabet kurallarının uygulanmasına ilişkin Konsey Tüzüğü, OJ L 1/1, 04.01.2003. "2. Idari süreçlerde tarafların savunma haklarına tam olarak riayet edilmelidir. Taraflara Komisyon nezdinde tutulan dosyaya erişim yetkisi tanınmalıdır. Fakat bu yetki diğer teşebbüslerin ticari sırlarının korunmasına ilişkin meşru menfaatleri ile sınırlıdır. Dosyaya erişim hakkı gizli bilgiler ve Komisyon ile Üye Devlet rekabet otoritelerinin iç yazışmalarını kapsamaz. Bu hak özellikle Komisyon ile Üye Devlet Rekabet Otoriteleri arası yazışmalar ile 11 ve 14. Maddeler uyarınca hazırlanan belgeleri de kapsayacak şekilde genişletilemez. Bu paragrafta belirtilen hiçbir ifade Komisyon'un belirli bir ihlali kanıtlaması için belirli bilgileri kullanmasını ve ifşa etmesini engelleyemez." https://eur-lex.europa.eu/legal-content/EN/ TXT/PDF/?uri=CELEX:32003R0001\&from=en, (16.02.2021).

16 Judgment of the Court of First Instance (GC) of 29 June 1995, T-30/91, Solvay v. Commission; Judgment of the Court of First Instance (GC) of 29 June 1995, T-36/91, Imperial Chemical Industries plc (ICI) v. Commission.

17 İyi yönetim bireylerin temel hak ve hürriyetlerini koruyup gözeten, haklı beklentileri karşılayan, güvenilen ve şeffaf bir idaredir. İyi yönetim hakkı ilk kez Avrupa Konseyi Bakanlar Komitesinin 28 Eylül 1977/31sayılı tavsiye kararı ile kabul edilmiştir. Söz konusu kararda bireyin idare karşısında korunması başlığı altında bireylerin kendileri hakkında bir karar alınmadan önce dinlenilmeleri gerektiği, idari kararlara katılma haklarının olduğu, bilgi kaynaklarına erişebilecekleri, hukuki yardım alabilecekleri, idari işlemlerin gerekçeli olmasının esas olduğu ve idari işleme karşı başvuru yollarının neler olduğunun belirtilmesi gerektiği ifade edilmiştir ve kararda Üye Devletlerin iç hukuklarında bu ilkelere uymaları tavsiye edilmiştir. ABIDA'nın 263 ve 228'inci maddeleri uyarınca iyi yönetim kurallarına uyulmaması halinde $A B$ vatandaşlarının ilgili kurum veya kuruluşlar aleyhine yargı yoluna başvurma yahut Ombudsman'a şikâyet etme hakları bulunmaktadır. Ayrıca 2007 yılında AB Bakanlar Komitesi CM/Rec (2007)7 sayı ile yayınlamış olduğu tavsiye kararında Üye Devletler tarafından uyulacak iyi 
Aslan, E.F. (2021). "Vergi/Ceza İhbarnamelerine Vergi İnceleme ve/veya Vergi Tekniği Raporlarının Eklenmemesinin İyi İdare ve Dosyaya Giriş Hakları Kapsamında Değerlendirilmesi", International Journal of Public Finance, 6(1), 115-136.

Bildirgesinin $^{18}$ 41(2)(b) maddesinde düzenlenmektedir (T.C. AB Bakanlı̆̆ı, 2013). Söz konusu maddeye göre herkes idari makamlarca kendisi hakkında tutulan dosyalara erişim hakkına sahiptir. Fakat söz konusu hak başkalarının gizlilikle ilgili meşru menfaatleri ile mesleki ve ticari sırlarının korunması ile sınırlıdır. Buna göre dosyaya erişim hakkının sınırı gizlilik ile mesleki ve ticari sırların korunması olarak karşımıza çıkmaktadır (Craig, 2014: 1082).

Bildirgenin yukarıda belirtilen 41(2)'inci maddesi ile 42. maddesi birbiriyle karıştırılmamalıdır. 41(2)'inci madde $A B$ kurumlarında tutulan belirli bir kişiyle ilgili dosyaların yani bilgi ve belgelerin savunma hakkı kapsamında sadece ilgilisine açılmasını konu edinirken Temel Haklar Bildirgesinin 42. maddesi ile Avrupa Birliği'nin İşleyişine Dair Anlaşma'nın (ABIDA)'nın 15(3)'üncü maddeleri ise AB kurum, ofis ve ajanslarının çalışmalarını şeffaf bir şekilde yürütmeleri ile ilgili olup anılan kuruluşlar bünyesinde tutulan tüm evrak ve dosyaların genel olarak kamuya açılmasıyla, bir diğer ifade ile kamunun bilgi edinme hakkı ile ilgilidir.

$A B$ kurumlarında tutulan belgelerin alenen kamuya açılması daha sıkı şartlara tabidir. ABIDA'nın $15^{\prime}$ inci maddesi uyarınca belgelerin hangi ilke, şart ve sınırlamalar kapsamında kamuya açılabileceğini Avrupa Parlamentosu ve Konseyi çıkaracağı Tüzüklerle belirleyecektir. Konsey konuyla ilgili 1049/2001 sayılı bir Tüzük çıkarmıştır. Bu noktada anılan Tüzüğün İstisnalar kenar başlıklı 4. maddesi ${ }^{19}$ uyarınca kamunun bilgi

yönetim ilkelerinin neler olduğuna detaylı bir şekilde yer vermiş ve kararın ekinde örnek nitelikte “Avrupa Doğru İdari Davranış Yasası'na” yer vermiştir. Bkz: https://www.ombudsman.europa.eu/lv/ publication/tr/3510, https://rm.coe.int/cmrec-2007-7-of-the-cm-to-ms-on-good-administration/ 16809f007c, (16.02.2021).

${ }^{18} 8$ Aralık 2000 tarihinde gerçekleştirilen Nice Zirvesi'nde katalog olarak ilan edilen Avrupa Birliği Temel Haklar Bildirgesi'ne, 1 Aralık 2009 tarihinde yürürlüğe giren Lizbon Antlaşmasıyla, Avrupa Birliği Antlaşmalarıyla aynı hukuki değere sahip bir düzenleme olarak bağlayıcı nitelik kazandırılmıştır. $A B$ Antlaşmasının 6. maddesinde zikredilen $A B$ Temel Haklar Bildirgesi $A B$ katılım sürecindeki ülkeler bakımından dikkate değer bir insan hakları kataloğu ve standardı oluşturmaktadır. Söz konusu 6 . maddenin ilk paragrafında "Birlik, Antlaşmalar ile aynı hukuki değere sahip olan ve 12 Aralık 2007 tarihinde Strazburg'da uyarlandığı şekliyle, 7 Aralık 2000 tarihli Avrupa Birliği Temel Haklar Şartı'nda yer alan hakları, özgürlükleri ve ilkeleri tanır" ve son paragrafında "Avrupa Insan Hakları ve Temel Özgürlüklerin Korunması Sözleşmesi tarafından güvence altına alınan ve üye devletlerin ortak anayasal geleneklerinden kaynaklanan temel haklar, Birlik hukukunun genel ilkelerinin parçasıdır" ifadelerine yer verilmektedir. Temel hak ve özgürlüklere saygı Türkiye'nin de AB üyeliği için belirleyici unsurdur. Bu husus Türkiye-AB ilişkilerinde sürekli şekilde ön planda olmuş, 1980 askeri darbesi sonrası gerçekleştirilen hukuka aykırı ve keyfi uygulamalar $A B^{\prime}$ nin Türkiye ile ilişkileri dondurmasının temel nedenini teşkil etmiştir. Yine 1987 yılında yapılan üyelik başvurusunun o dönemde olumlu yanıtlanmamasının nedenleri arasında Türkiye'deki siyasal durum ve insan hak ve temel özgürlüklerin korunmasındaki yetersizliklere işaret edilmiş, 1997 yılında AB'nin genişleme stratejisinde Türkiye'ye aday ülke olarak yer verilmemesine neden olarak ise yine en başta insan hak ihlalleri gösterilmiştir. İzah olunan önem nedeniyle AB'nin Türkiye için yayımladı̆̆ belgeler ve değerlendirmelerde en fazla dikkat çekilen alan insan hakları ve temel özgürlüklerdir. Bu nedenle, Türkiye'nin 2000'lerde yoğun reform çabasına girdiği alanların başında da temel hak ve özgürlüklerin güçlendirilmesi gelmektedir.

19 "Madde 4 istisnalar

1. Kurumlar belirli bir belgeye erişimi aşağıda belirtilen hususların korunması amacıyla reddedebilirler:

(a) Belirtilen bir kamu yararı olması:

- kamunun güvenliği 
Aslan, E.F. (2021). "Vergi/Ceza İhbarnamelerine Vergi İnceleme ve/veya Vergi Tekniği Raporlarının Eklenmemesinin İyi İdare ve Dosyaya Giriş Hakları Kapsamında Değerlendirilmesi", International Journal of Public Finance, 6(1), 115-136.

edinme hakkı özellikle ilgili kuruluşlar tarafından yürütülen denetim, inceleme ve soruşturmaların korunması amacıyla sınırlandırılabilecektir ${ }^{20}$.

\subsection{Türk Hukukunda İyi Yönetim Kapsamında Bilgi Edinme ve Dosyaya Giriş Hakkı}

Her ne kadar ABIDA ve dolayısıyla $A B$ Temel Haklar Bildirgesi Türkiye için doğrudan bağlayıcı hukuk kaynakları olmasa da ülkemizde $A B$ hukukuna kayıtsız kalınmamasında fayda vardır. Zira Anayasa'da 2001 ve 2004 yıllarında AB hukukuna uyum amacıyla yapılan değişiklikler kanun koyucunun bu yöndeki iradesini göstermektedir. Ayrıca Türkiye ile AB arasında Gümrük Birliği'ni oluşturan 5 Mart 1995 tarihinde alınan 1/95 sayılı Ortaklık Konseyi Kararı (OKK) ve 12 Eylül 1963 tarihli Ankara Anlaşması'nın 10. maddesi nedeniyle Türkiye'nin $A B$ ile olan ticareti sebebiyle $A B$ hukuk sistemine uyum göstermesi gerekmektedir (Aslan, 2020: 73). Bu kapsamda Ankara Anlaşması ve 1/95 sayılı OKK uyarınca Türkiye'nin $A B$ rekabet hukuku, fikri ve

- savunma ve askeri konular

- uluslararası ilişkiler

- Topluluğun veya belirli bir Üye Devletin finans, para veya ekonomi politikası

(b) Özellikle Topluluğunun kişisel verilerin korunması mevzuatına uygun şekilde gizliliğinin veya bireyin bütünlüğünün korunması

2. Kurumlar (ilgili belgelerin ifşa edilmesinde daha üstün bir kamu yararı yoksa) erişimi aşağıda belirtilen hususların korunması amacıyla reddedebilirler:

- Gerçek veya tüzel bir kişinin mülkiyet hakkı dahil ticari menfaatleri

- Mahkeme süreçleri ve hukuki danışmanlık

- inceleme, soruşturma ve denetimler

3. Belirli bir kurumun iç işlerinde kullanılmak üzere hazırlanmış olan ya da belirli bir kurum tarafından tebliğ alınan fakat söz konusu kurumun kendi vereceği kararda kullanılmayacak olan bir belgeye erişim talep edildiğinde (belgenin ifşa edilmesinde daha üstün bir kamu yararı yoksa) ilgili kurumun karar alma sürecinin ciddi bir şekilde zarar göreceği gerekçesi ile anılan belgeye erişim talebi reddedilebilir.

Danışmanlık kapsamında hazırlanan ve ilgili kurumun iç işlerinde kullanılması için görüşler içeren belgelere erişim talepleri, ifşa edilmelerinde daha üstün bir kamu yararının bulunmaması durumunda ve ilgili kurumun karar alma süreçlerini ciddi şekilde olumsuz etkileyeceğinde, kararın alınmasından sonraki aşamada dahi reddedilebilir.

4. Üçüncü kişilerle ilgili belgeler hakkında ise, (belgelerin ifşa edilmelerinin mümkün olup olmadığı açıkça anlaşılamıyorsa) ilgili kurumun söz konusu üçüncü kişilere 1. ve 2. Paragraflarda belirtilen istisnaların uygulanma alanı olup olmadığını anlamak amacıla danışması gerekir.

5. Belirli bir üye devlet kurumların kendisinden izin alınmaksızın kendisinden türemiş olan belgeleri ifşa etmemesini talep edebilir.

6. Talep edilen belgelerin sadece belirli bölümleri belirtilen istisnalar kapsamında ise geri kalan kısımlarının ifşa edilmesi gerekir.

7. 1 ila 3. paragraflar arasında belirtilen istisnalar ilgili belgenin içeriğine göre haklı görülecek süre boyunca uygulanır. Istisnaların uygulanma süresi azami 30 yıldır. Fakat belgelerin gizlilik ve ticari menfaatlerle ilgili istisnalar kapsamına girmesi veya hassas nitelikte olması halinde ve gerekli görülmesi durumunda süre 30 yıldan sonra da devam eder."

20 Policy Department for Budgetary Affairs Directorate General for Internal Policies of the Union (2017), The protection of the procedural rights of persons concerned by OLAF administrative investigations and the admissibility of OLAF Final Reports as criminal evidence, PE 603.790, Brussels. https://www.europarl.europa.eu/RegData/etudes/IDAN/2017/603790/IPOL_IDA(2017)603790_EN. pdf, (16.02.2021). 
Aslan, E.F. (2021). "Vergi/Ceza İhbarnamelerine Vergi İnceleme ve/veya Vergi Tekniği Raporlarının Eklenmemesinin İyi İdare ve Dosyaya Giriş Hakları Kapsamında Değerlendirilmesi", International Journal of Public Finance, 6(1), 115-136.

sınai mülkiyet hukuku vb. gibi mali konularda da $A B$ mevzuatına uyum yükümlülüğü doğmuştur ${ }^{21}$.

Bu doğrultuda esasen $A B$ hukuku düzenlemelerinin Türk iç hukukunda mevzuat çalışmaları yapılırken dikkate alındığı görülmektedir. Aksi bir durum ülkemizin Ankara Anlaşması ve OKK uyarınca üstlendiği yükümlülüklerini yerine getirmemesi anlamına gelecektir ve Anayasa'nın 90(5)'inci maddesine ${ }^{22}$ de aykırılık teşkil edecektir.

\subsubsection{Bilgi Edinme Hakkı}

Bir önceki bölümde belirtilen nedenlerle önce 2003 yılında, EC No 1049/2001 sayılı, 30 Mayıs 2001 tarihli, Avrupa Parlamentosu, Konseyi ve Komisyonu belgelerinin kamusal erişimi hakkında Tüzük hükümlerini esas alan, 4982 sayılı Bilgi Edinme Kanunu'nun, Bilgi Edinme Hakkı Kanununun Uygulanmasına iliş̧kin Esas ve Usuller Hakkında Yönetmelik'in ve İçişleri Bakanlığınca Bilgi Edinme Hakkı Kanununun Uygulanması ile ilgili Olarak Yürütülecek İşlemlere İlişkin Yönerge'nin ${ }^{23}$ çıkarıldığı görülmektedir.

Bilgi edinme hakkı, "gerçek ve tüzel kişilerin kamu kurum ve kuruluşlarının görevleri icabı elde ettikleri bilgilere erişim hakkı" olarak tanımlanabilir. Bu hak, ilgililer tarafından idareye yapılacak bilgi edinme başvuruları dışında, idarenin kendi takdiri ile erişime açtığı bilgi ve belgeleri de kapsar. Bilgi edinme hakkı kapsamında yapılan bir başvurunun reddedilmesi halinde, ret kararının gerekçesinin, karara karşı başvuru yollarının ve sürelerinin başvuru sahibine bildirilmesi zorunludur. Bilgi edinme başvurularının idare tarafından reddedilebilmesi için yalnızca ilgili mevzuatta belirtilen istisnaların gerçekleşmiş olması gerekir (BEDK, 2015).

Bilgi Edinme Kanunu'nun 9'uncu maddesine göre “istenen bilgi veya belgelerde, gizlilik dereceli veya açıklanması yasaklanan bilgiler ile açıklanabilir nitelikte olanlar birlikte bulunuyor ve bunlar birbirlerinden ayrılabiliyorsa, söz konusu bilgi veya belge, gizlilik dereceli veya açıklanması yasaklanan bilgiler çıkarıldıktan sonra başvuranın bilgisine sunulur ve ayırma gerekçesi başvurana yazılı olarak bildirilir." Yine söz konusu Kanun'un 21'inci maddesi uyarınca üçüncü kişilere ait kişisel veriler, mesleki, ekonomik, özel hayata ilişkin yahut gizli bilgiler söz konusu kişilerin açık yazılı rızaları alınmak suretiyle kamuya açıklanabilir.

Benzer şekilde 22'inci maddede de gizliliği talep edilmemiş olan üçüncü kişilere ait ticari sır niteliğinde bilgilerin kamu kurum ve kuruluşları tarafından kamuya açılabileceği ifade edilmektedir. Bilgi Edinme Kanunu'nun 14. maddesi ile Bilgi Edinme

${ }^{21}$ https://www.ab.gov.tr/gumruk-birligi_46234.html, (16.02.2020).

22 “Usulüne göre yürürlüğe konulmuş Milletlerarası andlaşmalar kanun hükmündedir. Bunlar hakkında Anayasaya aykırılık iddiası ile Anayasa Mahkemesine başvurulamaz. Usulüne göre yürürlüğe konulmuş temel hak ve özgürlüklere ilişkin milletlerarası andlaşmalarla kanunların aynı konuda farklı hükümler içermesi nedeniyle çıkabilecek uyuşmazlıklarda milletlerarası andlaşma hükümleri esas alınır."

23 https://www.icisleri.gov.tr/illeridaresi/i-isleri-bakanliginca-bilgi-edinme-hakki-kanunununuygulanmasi-ile-ilgili-olarak-y-r-t-lecek-islemlere-iliskin-y-nerge, (16.02.2021). 
Aslan, E.F. (2021). "Vergi/Ceza İhbarnamelerine Vergi İnceleme ve/veya Vergi Tekniği Raporlarının Eklenmemesinin İyi İdare ve Dosyaya Giriş Hakları Kapsamında Değerlendirilmesi",

International Journal of Public Finance, 6(1), 115-136.

Değerlendirme Kurulu (BEDK) oluşturulmuştur. Söz konusu kurul bilgi edinme başvurularına muhatap olan idari kurum ve kuruluşlar tarafından verilen kararlar hakkında ilgilileri tarafından yapılan itirazları inceler ${ }^{24}$.

Bilgi Edinme Kanunu'nun çıkarılmasının ardından 2010 yılında Anayasa'nın 74'üncü maddesi değiştirilerek Türkiye'de ikamet eden herkesin kamu ile ilgili dilek ve şikayetleri hakkında yetkili makamlara ve TBMM'ye dilekçe ile başvurma ve bilgi edinme hakkı olduğunu belirten bir düzenleme getirilerek söz konusu hak Anayasal güvence altına alınmıştır.

Dilekçe Hakkı 1984 tarihli, Dilekçe Hakkının Kullanılmasına Dair 3071 sayılı Kanun hükümlerine göre kullanılır. Kanun, Türk vatandaşları ve Türkiye'de ikamet eden yabancılar tarafından TBMM ile idarî makamlara yapılan dilek ve şikâyetler hakkındaki başvuruları kapsar. Bilgi edinme başvuruları ile dilekçe hakkının kullanılması birbirine karıştırılmamalıdır. Bilgi edinme hakkı ile kişiler, kurum ve kuruluşların kayıtlarında bulunan bilgi ve belgeleri talep ederler. Dilekçe hakkı ise kişilerin dilek, istek, şikâyet ve ihbarlarını ilgili kurum ve kuruluşlara iletebilmelerini sağlayan bir haktır (BEDK, 2015: 11). Bilgi edinme hakkı kapsamında belirli bir idari kuruluşa başvuru yapan kişiler, başvurularına verilecek yanıt hakkında ortaya çıkabilecek itiraz ve şikayetlerini sadece Bilgi Edinme Değerlendirme Kurulu'na değil; aynı zamanda idare mahkemelerine ya da Kamu Denetçiliği Kurumu'na da iletebilirler (BEDK, 2015: 27). Şikâyette bulunulabilecek merciler bakımından hukuken bir yarışma söz konusudur.

Bilgi edinme hakkının kullanılmasına ilişkin olsun ya da olmasın idarenin işleyişi ile ilgili her türlü şikâyetler 2012 yılında yürürlüğe giren 6328 sayılı Kamu Denetçiliği (Ombudsmanlık ${ }^{25}$ ) (Yaltı, 2012: 112) Kurumu Kanunu uyarınca TBMM'ye bağlı Kamu Denetçiliği Kurumu'na yapılır. Söz konusu Kanunun 1. maddesi uyarınca kamu hizmetlerinin işleyişinde bağımsız ve etkin bir şikâyet mekanizması oluşturmak suretiyle, idarenin her türlü eylem ve işlemleri ile tutum ve davranışlarını; insan haklarına dayalı adalet anlayışı içinde, hukuka ve hakkaniyete uygunluk yönlerinden incelemek, araştırmak ve önerilerde bulunmak üzere Kamu Denetçiliği Kurumunu oluşturmayı amaçlamaktadır.

Kamu Denetçiliği Kurumu 2013 yılında faaliyete başlamıştır ve aldığı kararlar ile idareye yol göstermektedir. Bu çerçevede Kamu Denetçiliği kurumunun başlıca

\footnotetext{
${ }^{24}$ Kurul; birer üyesi Yargıtay ve Danıştay genel kurullarının kendi kurumları içinden önerecekleri ikişer aday, birer üyesi ceza hukuku, idare hukuku ve anayasa hukuku alanlarında profesör veya doçent unvanına sahip kişiler, bir üyesi Türkiye Barolar Birliğinin baro başkanı seçilme yeterliliğine sahip kişiler içinden göstereceği iki aday, iki üyesi en az genel müdür düzeyinde görev yapmakta olanlar ve bir üyesi de Adalet Bakanının önerisi üzerine bu Bakanlıkta idarî görevlerde çalışan hâkimler arasından Cumhurbaşkanınca seçilecek dokuz üyeden oluşur. 07.06.2006 tarihli ve 26191 sayılı Resmî Gazete ile Bilgi Edinme Değerlendirme Kurulunun Çalışma Usul ve Esasları Hakkında Yönetmelik yürürlüğe girmiştir. 10.04.2019 tarihli ve 30741sayılı Resmî Gazete'de yayımlanan 09.04.2019 tarihli ve 865 sayılı Cumhurbaşkanı Kararı uyarınca bu Yönetmelik Cumhurbaşkanlığı Yönetmeliği bölümüne eklenmiştir. https://bedk.adalet.gov.tr/, (16.02.2021).

25 'Ombudsman, 'temsilci', 'sözcü', 'koruyucu', 'arabulucu' anlamlarına gelen bir terimdir. Kamu makamlarının yapmış olduğu işlemleri Parlamento adına denetleyen bağımsız ve tarafsı bir kurum olarak tanımlanabilir."
} 
Aslan, E.F. (2021). "Vergi/Ceza İhbarnamelerine Vergi İnceleme ve/veya Vergi Tekniği Raporlarının Eklenmemesinin İyi İdare ve Dosyaya Giriş Hakları Kapsamında Değerlendirilmesi", International Journal of Public Finance, 6(1), 115-136.

amaçları idarenin hizmet kalitesinin yükseltilmesi, "iyi yönetim ilkelerinin yerleşmesi", insan haklarının gelişmesi, hukukun üstünlüğünün sağlanması, hak arama kültürünün yaygınlaşması, şeffaf hesap verebilir, insan odaklı bir idarenin oluşturulması olarak karşımıza çıkmaktadır ${ }^{26}$.

Kamu Denetçiliği Kurumu Kanununun Uygulanmasına İlişkin Usul ve Esaslar Hakkında Yönetmelik'in 6'ıncı maddesinde $A B$ Insan Hakları Bildirgesinde ve Avrupa Doğru İdari Davranış Yasasında yer alan iyi yönetim ilkelerine (Halimovski, 2016: 80100) yer verildiği ve uygulamada da idarenin söz konusu ilkelere uygun davranıp davranmadığının değerlendirildiği görülmektedir ${ }^{27}$. Söz konusu madde şu şekildedir:

"Iyi yönetim ilkeleri

MADDE 6 - (1) Kurum, inceleme ve araştırma yaparken idarenin, insan haklarına dayalı adalet anlayışı içinde; kanunlara uygunluk, ayrımcılığın önlenmesi, ölçülülük, yetkinin kötüye kullanılmaması, eşitlik, tarafsızlık, dürüstlük, nezaket, şeffaflık, hesap verilebilirlik, haklı beklentiye uygunluk, kazanılmış hakların korunması, dinlenilme hakkı, savunma hakkı, bilgi edinme hakkı, makul sürede karar verme, kararların gerekçeli olması, karara karşı başvuru yollarının gösterilmesi, kararın geciktirilmeksizin bildirilmesi, kişisel verilerin korunması gibi iyi yönetim ilkelerine uygun işlem ve eylem ile tutum veya davranışta bulunup bulunmadığını gözetir ve iyi yönetim ilkelerine uyar."

Kamu Denetçiliği Kurumu idarenin işlem ve eylemleri bakımından bir denetim mekanizması getirmektedir. Fakat bu denetim yargılama faaliyeti niteliğinde değildir. Bir diğer ifade ile Kamu Denetçiliği Kurumu mahkemelerin yargı yetkisi ile kıyaslanabilecek yetkileri bulunan bir idari otorite değildir. Kurumun idari yargıyı tamamlayıcı, tali nitelikli bir işlevi vardır. Zaten Kurum tarafından alınan kararlar bağlayıcı değil, tavsiye niteliğindedir. Kurum kararları esas olarak idarenin belirli bir işleminin geri alınmasının veya değiştirilmesinin önerilmesi şeklindedir. Dolayısıyla Kurumun yarı yargısal bir mahiyet taşıdığı ifade edilebilir. Kurumun bağımsız ve tarafsız olması esas olup ${ }^{28}$ (Şenyüz, 2020: 290) geleneksel uyuşmazlık çözüm yöntemlerine kıyasla daha hızlı, esnek, masrafsız ve kolay bir alternatif sunar. İdare ile vatandaşlar arasındaki uyuşmazlıkların yargı dışı alternatif çözüm yollarından biri olarak Kamu Denetçiliği Kurumu'nun yargı üzerindeki iş yükünü azaltıcı bir fonksiyonu olduğu da ifade edilebilecektir (Yaltı, 2012: 114).

${ }^{26}$ https://www.ombudsman.gov.tr/hakkimizda/index.html, (16.02.2021).

27 Bkz. T.C. Kamu Denetçiliği Kurumu'nun 2016/54 şikâyet numaralı, 18.06.2016 tarihli kararı, p. 26-27. https://www.ombudsman.gov.tr/contents/files/Bilgi\%20ve\%20Belgelerin\%20Bilgi\%20Edinme\%20Hak k\%C3\%84\%C2\%B1\%20Kapsam\%C3\%84\%C2\%B1nda\%20Kendisine\%20Verilmesi\%20Talebi\%20Hakk\%C 3\%84\%C2\%B1nda(1).pdf, (16.02.2021).

28 "Kurumun bağımsızlığı yasa ile teminat altına alınmıştır. Hiçbir organ, makam merci veya kişi, baş denetçiye veya denetçilere görevleriyle ilgili olarak emir ve talimat veremez, genelge gönderemez, tavsiye ve telkinde bulunamaz. Başdenetçi ve denetçiler de görevlerini yerine getirirken tarafsızlık ilkesine uygun davranmak zorundadır." 
Aslan, E.F. (2021). "Vergi/Ceza İhbarnamelerine Vergi İnceleme ve/veya Vergi Tekniği Raporlarının Eklenmemesinin İyi İdare ve Dosyaya Giriş Hakları Kapsamında Değerlendirilmesi", International Journal of Public Finance, 6(1), 115-136.

\subsubsection{Dosyaya Giriş Hakkı}

Türk Rekabet Hukukunda savunma hakkının bir parçası olan dosyaya giriş hakkına ilişkin esaslar ise, (1/2003 sayılı, 16 Aralık 2002 tarihli Anlaşmanın 81 ve 82'inci maddelerinde belirtilen rekabet kurallarının uygulanmasına ilişkin Konsey Tüzüğü hükümleri dikkate alınarak) yine 2010 yılında "Dosyaya Giriş Hakkının Düzenlenmesine ve Ticari Sırların Korunmasına iliş̧kin 2010/3 sayılı Tebliğ" ile düzenlenmiştir (Aslan, 2017: 1253). Söz konusu tebliğin 6. maddesi uyarınca "haklarında soruşturma açılan ya da nihai inceleme başlatılan teşebbüs veya teşebbüs birlikleri, dosyaya giriş hakkı kapsamında, Kurum içi yazışmalar ve başka teşebbüs, teşebbüs birliği ve kişilere ilişkin ticari sır ve diğer gizli bilgileri içerenler hariç olmak üzere, Kurum bünyesinde kendileri ile ilgili düzenlenmiş her türlü evraka ve elde edilmiş olan her türlü delile erişebilirler". Yine aynı tebliğin 8. maddesinin 1. fıkrasına göre de "haklarında soruşturmaya başlandığı bildirilen taraflar, Kurum bünyesinde kendileri ile ilgili düzenlenmiş her türlü evrakın ve mümkünse elde edilmiş olan her türlü delilin bir nüshasının kendilerine verilmesini isteyebilirler" ${ }^{\prime 29}$.

Uygulamada Rekabet Kurumu birden fazla teşebbüsü aynı soruşturma kapsamında incelediğinde bunlarla ilgili tek soruşturma raporu (ve ek görüş) hazırlar ve aynı raporu ticari sırlardan arındırılmış şekilde tüm teşebbüslere iletir (Korkmaz, 2020: $32,40)$. Raporun giriş gelişme, sonuç ve ek listesi gibi bölümleri konuyla ilgili genel bilgileri içerdiği için değiştirilmeksizin tüm teşebbüslere aynı şekilde iletilir. Raporun her bir teşebbüsle ilgili bireysel ihlal iddialarının incelendiği bölümleri ise ayrı başlıklar halinde kaleme alınır. Belirli bir teşebbüsle ilgili ihlal iddialarının incelendiği bölümün soruşturma kapsamında olan başka bir teşebbüsü hiç ilgilendirmediği hallerde raporun söz konusu bölümü yalnızca ilgili teşebbüse tebliğ edilir ve diğer teşebbüslere gönderilmez. Fakat anılan bölümlerde belirli bir teşebbüsten elde edilen ve başka bir teşebbüsün aleyhine (veya lehine) de delil olarak gösterilen bilgi ve belgelerin bulunması durumunda ticari sırların korunması bahane edilerek söz konusu bölümün saklanması, gizlenmesi ve ilgili diğer teşebbüslere gösterilmemesi mümkün değildir ${ }^{30}$ (Güngördü \& Koyuncu, 2014: 92). Bu tip durumlarda ilk teşebbüsün ticari sırlarının ifşa edilmemesi amacıyla ilgili kısımlar ticari sırlardan arındırılarak (karartma yapılarak) ${ }^{31}$

29 Dosyaya giriş hakkı tanımı ve kapsamına ilişkin olarak bkz. Rekabet Kurumu'nun 20-44/607-268 sayılı, 01.10.2020 tarihli kararı. https://www.rekabet.gov.tr/Karar?kararld=bcdf271b-67f3-46e4-8a782466459092f7, (16.02.2021).

30 "Bakılan uyuşmazlıkta, davacı şirketin, hakkında açılan soruşturma kapsamında, soruşturma raporunun ekinde bulunan ve soruşturma raporu değerlendirme sürecinde değerlendirmeye alınmış olma ihtimali olan kendileriyle ilgili tüm bilgi ve belgelerin istenilmesine ilişkin yaptığı başvurunun kısmen reddine ilişkin davalı idare işleminin, idari işlem teorisi anlamında soruşturma sürecinden ayrılabilir bir karar olarak, davacının hukukunda etkili olan ve idari davaya konu edilebilecek kesin ve yürütülebilir nitelikte bir işlem olduğundan davanın incelenmeksizin reddi yolundaki Mahkeme kararında usul ve kurallarına uygunluk bulunmamaktadır". Danıştay 13. Dairesinin 09.09.2013 tarihli E. 2013/1663, K. 2013/2144 sayılı kararı.

31 Teşebbüsler hakkında gizli bilgi içeren bölümlerin karartılması işlemi Kurum çalışanları tarafından yapılmamaktadır. Aksine ilgili tebliğin 13 ila 15. maddeleri arasında Kurum tarafından talep edilen bilgi ve belgeleri sunan teşebbüslerin ticari sır ve gizlilik bildirimini nasıl yapacakları ve sundukları evrakların gizli bilgi içermeyen nüshalarını ne şekilde hazırlayacaklarına ilişkin detaylara yer 
Aslan, E.F. (2021). "Vergi/Ceza İhbarnamelerine Vergi İnceleme ve/veya Vergi Tekniği Raporlarının Eklenmemesinin İyi İdare ve Dosyaya Giriş Hakları Kapsamında Değerlendirilmesi", International Journal of Public Finance, 6(1), 115-136.

diğer teşebbüslere de iletilir ${ }^{32}$. Böylece söz konusu teşebbüsler kendilerine yöneltilen ihlal iddiaları hakkında bilgi edinmiş olurlar ve savunma hakları sınırlandırımamış olur ${ }^{33}$.

Rekabet Kurumu'nun yürüttüğü soruşturma süreçlerinde ilgililerin kendileri hakkında tutulan dosyalara erişme haklarına ilişkin usul ve esasları düzenleyen kuralların tıpkı $A B$ hukukunda olduğu gibi genişletilerek kıyasen başta vergi daireleri olmak üzere diğer tüm idari makamlar nezdinde yürütülen inceleme, denetim vb. süreçlerde de dikkate alınması gerektiği düşünülmektedir.

\section{Sonuç ve Öneriler}

Yukarıda detaylı olarak izah ettiğimiz üzere adil yargılanma ve savunma hakkının bir uzantısı olan bilgi edinme ve dosyaya erişim hakkı $A B$ idare hukukuna $A B$ rekabet hukuku içtihadından türeyerek genişlemiş ve iyi yönetim hakkı adı altında $A B$ İnsan Hakları Bildirgesi ile de koruma altına alınmış bir haktır.

Türk Hukukunda öncelikle 2003 yılında Bilgi Edinme Kanunu kapsamında iç hukukumuza girmiş olan iyi yönetim hakkı, 2010 yıııın Nisan ayında Rekabet Kurumu tarafından yayınlanmış olan Dosyaya Giriş Hakkının Düzenlenmesine ve Ticari Sırların Korunmasına îlişkin Tebliğ ile genişlemiştir. Ardından yine aynı yılın mayıs ayında Anayasa'nın 74. Maddesinde yapılan değişiklikler ile Anayasal güvence altına alınmıştır. Söz konusu koruma 2012 yılında yürürlüğe giren Kamu Denetçiliği Kurumu Hakkında Kanun ve alt mevzuatı ile de iyice pekiştirilmiştir.

Öncelikle rekabet hukuku uygulamasında kendine yer bulmuş olan dosyaya giriş hakkının sadece Rekabet Kurumu nezdinde değil, diğer tüm idari kurum ve kuruluşlar nezdinde yürütülen her türlü idari süreçlerde tanınması ve korunması gerektiği düşünülmektedir. Zira Kamu Denetçiliği Kurumu Hakkında Kanun'un 1. maddesinin ve söz konusu Kanun'un Uygulanmasına iliş̧kin Usul ve Esaslar Hakkında Yönetmeliğin 6. maddesinde yer alan iyi yönetim ilkelerinin gereği olarak vatandaşlara başta kendileriyle ilgili olmak üzere idareler nezdinde tutulan her türlü dosya, bilgi ve belgeye erişim imkânının sağlanması gerekmektedir.

Bu durumda vergi idaresinin de mükellefler hakkında düzenlediği vergi inceleme raporlarını ve/ veya vergi tekniği raporlarını, vergi/ceza ihbarnameleri ile birlikte mükelleflere tebliğ etmesi gerekmektedir. Tebligatın eksik kalması ve mükellef tarafından ilgili raporların talep edilmesi durumunda ivedilikle söz konusu raporların dava aşamasından önce mükellefe iletilmesi daha uygun olacaktır.

verilmektedir. Yani teşebbüsler soruşturma kapsamında kullanılacak evraklarının soruşturma esnasında ya da nihai karar yayınlandıktan sonra diğer teşebbüslere ve kamuoyuna açılması halinde ticari sırlarının ve gizli bilgilerinin ifşa olmaması için henüz soruşturma başında ilgili belgeler üzerinde bizzat karartma uygulamaktadırlar.

32 Bkz. Rekabet Kurulu'nun 20-18/245-117 sayılı, 02.04.2020 tarihli kararı.

33 Rekabet soruşturmalarında dosyaya giriş hakkının kapsamının ne olduğunun yargı aşamasında tartışıldığı örnek bir karar için bkz. Ankara 9. İdare Mahkemesi E.2018/1189- K. 2019-2054, 16.10.2019. https://www.rekabet.gov.tr/Safahat?safahatld=63759a65-4cf1-4489-a96f-294de23ed9f5 (16.02.2021). 
Aslan, E.F. (2021). "Vergi/Ceza İhbarnamelerine Vergi İnceleme ve/veya Vergi Tekniği Raporlarının Eklenmemesinin İyi İdare ve Dosyaya Giriş Hakları Kapsamında Değerlendirilmesi", International Journal of Public Finance, 6(1), 115-136.

Yine bu yönde, Dosyaya Giriş Hakkının Düzenlenmesine ve Ticari Sırların Korunmasına İlişkin Tebliğ hükümleri ile Bilgi Edinme Kanunu'nun 9, 21 ve 22'inci maddeleri dikkate alınarak Vergi Denetim Kurulu Yönetmeliği'nin 57/4. maddesinin de değiştirilmesi gerektiği düşünülmektedir ${ }^{34}$. Zira uygulamada mevcut düzenlemeye uygun davranılmamakta ve maddenin idareye tanıdığı takdir hakkı nedeniyle mükelleflere kendilerini suçlayan VTR'ler hakkında vergi mahremiyetinin korunması bahanesi ile yeterli bilgi sunulmamaktadır.

Bu sorunu ortadan kaldırmak amacıyla bir mükellef hakkında hazırlanan VTR'de başka bir mükellefin sahte belge kullandığına ilişkin bilgi ve belgelere yer veriliyorsa, söz konusu raporun anılan mükellefle ilgili bölümlerinin ticari sırlardan ve diğer gizli bilgilerden arındırılmak (karartma yapılmak) suretiyle yahut sahibinin açık yazılı izni olması durumunda karartma yapılmaksızın ilgili mükellefe kendisiyle alakalı olarak hazırlanan VTR'ye ek yapılarak tebliğ edilmesinin zorunlu tutulması yönteminin benimsenmesi gerektiği düşünülmektedir. Bu yönde Vergi Usul Kanunu'nun vergi mahremiyeti ile ilgili $5^{\prime}$ inci maddesinde belirtilen istisnalar ${ }^{35}$ arasına da konuyla ilgili ekleme yapılmasının da uygun olabileceği kanaatindeyiz.

Fakat çalışmamızda belirtilen güncel Danıştay VDDK ve Anayasa Mahkemesi kararları nedeniyle mükellefler tarafından yargı yoluna başvurularak idarenin VUK'nun 35(2)'inci maddesine ve Vergi Denetim Kurulu Yönetmeliği'nin 57(4)'üncü maddesine uygun davranmasını beklemek pek de mümkün olamayabilecektir. Ayrıca yine aynı sebeple idarenin kendi kendine anılan yönetmelik maddesini değiştirmesi de pek olanaklı görülmemektedir. Fakat kanımızca halen konuyla ilgili olarak Bilgi Edinme Değerlendirme Kurulu'na (BEDK) veya Kamu Denetçiliği Kurumuna (KDK) başvuru yolu açıktır (Gümüşkaya, 2016: 288-289).

Mükelleflerin hangi kurumu seçecekleri noktasında akıllarında soru işareti oluşması durumunda doğrudan idarenin eylem ve işlemlerinin denetlenmesi ile ilgili

${ }^{34}$ Söz konusu maddenin şu şekilde değiştirilebileceği değerlendirilmektedir: Sahte belge düzenleme fiili dolayısıyla düzenlenen Vergi Tekniği Raporunun başka bir mükellefin sahte belge kullandığına ilişkin tespitler içermesi durumunda, söz konusu Vergi Tekniği Raporu, sahte belge kullanan mükellef nezdinde düzenlenecek vergi inceleme raporlarına eklenir. Ancak, söz konusu Vergi Tekniği Raporu gönderilmeden önce ilgilisi mükellefe rapor içeriğinde yer alan, üçüncü kişilerin görmesini istemediği ticari sır niteliğindeki bilgilerini karartması için makul süre verilir.

35 VUK'un 5. maddesinde hali hazırda belirtilen vergi mahremiyeti istisnaları özetle şunlardır: 1- Gelir ve kurumlar vergisi mükelleflerinin kimlik, matrah ve vergi bilgilerini içeren cetvellerin ve ilgili vergi dairesine asılması, 2- Maliye Bakanlığı tarafından vergi asıl ve cezalarının açıklanması, 3- Adli ve idari soruşturmalar kapsamında ilgililerden bilgi talep edilmesi, 4- Bankalarca vergi tahsilatı yapılabilmesi amacıyla sunulan bilgiler, 5- Sahte veya muhteviyatı itibarıyla yanıltıcı belge düzenleyen veya kullanan mükelleflerin bağıı oldukları meslek odalarına bu konuyla ilgili bildirimde bulunulması, 6- Gelir vergisi mükelleflerine ve sermaye şirketlerine vergi levhası asma mükellefiyeti getirilmesi, 7- Kamu kurum ve kuruluşları tarafından görevleri icabı mükelleflerden bilgi talep edilmesi. Kanımızca "bir mükellefin bizzat kendisiyle ilgili hazırlanan veya bizzat kendisiyle ilgili olarak hazırlanmasa dahi kendisi ile ilgili bilgiler içeren vergi inceleme raporlarının ve vergi tekniği raporlarının, yine kendisine gönderilen vergi ve ceza ihbarnamelerine eklenmesinin mecbur olması" da ayrı bir istisna kalemi olarak düzenlenebilir ve konuyla ilgili detayların ayrı bir yönetmelikle düzenleneceği belirtilebilir. 
Aslan, E.F. (2021). "Vergi/Ceza İhbarnamelerine Vergi İnceleme ve/veya Vergi Tekniği Raporlarının Eklenmemesinin İyi İdare ve Dosyaya Giriş Hakları Kapsamında Değerlendirilmesi", International Journal of Public Finance, 6(1), 115-136.

olduğu için KDK'nın tercih edilmesinin daha doğru olacağı düşünülmektedir (Saban, 2020: 476). Her ne kadar KDK Kanunu'nun 17 (4)'üncü maddesi uyarınca doğrudan menfaat sahibi olmayanlar iYUK'ta belirtilen idari başvuru yollarını tüketmeksizin (yani bu durumda kendisine VTR ya da ViR tebliğ edilmeyen mükellefler dışında kalan kişiler) başvuru yapamayacak ve 5 . madde uyarınca KDK tarafından lehe verilecek karar idareye sunulacak öneri niteliğinde olup, bağlayıcı olmayacaksa da yine de söz konusu kararın hukuk dünyasında etkili olabileceği düşünülmektedir ${ }^{36}$ (Yaltı, 2012: 114).

Zira ilgili kanunun 22. maddesi uyarınca KDK, her yıl sonunda faaliyetleri ve önerileri hakkında bir rapor hazırlayarak TBMM Dilekçe Komisyonu ile İnsan Haklarını Inceleme Komisyonu üyelerinden oluşan Karma Komisyona sunar. Komisyon, bu raporu iki ay içinde görüşüp kendi kanaat ve görüşlerini de içerecek şekilde özetleyerek TBMM Genel Kurulu'na sunulmak üzere TBMM Başkanlığı'na gönderir. Nihayet Komisyon raporu Genel Kurulda ivedilikle görüşülür. Belki de KDK'dan alınacak bir karar sayesinde doğrudan TBMM'yi mevzuat değişikliği yapılması konusunda ikna etmek mümkün olabilecektir.

Diğer bir intimalle de KDK kararından sonra açılacak bir davada çalışmamızda bahsedilen mahkeme kararları yerine söz konusu kararın güçlü bir delil olarak kullanılabileceği değerlendirilebilir. Fakat KDK Kanunu'nun 5(2)(b) ve 17(3)(b) maddeleri sebebiyle yargı yetkisinin kullanılmasına ilişkin kararlar kurumun yetki alanı dışında olup yargı organları tarafından görülmekte olan veya yargı organlarınca karara bağlanmış uyuşmazlıklarla ilgili olarak yapılan başvurular KDK tarafından incelenememektedir.

Bu nedenle menfaat sahibi mükelleflerin dava açmadan önce KDK'ya başvuruda bulunmaları ve KDK bir karar verene değin dava açmaktan imtina etmeleri önem arz etmektedir. Yine aynı maddenin 8. fıkrasına göre dava açma süresi içerisinde KDK'ya yapılan başvurular dava açma süresini durdurmaktadır ve süre söz konusu Kanun'un 21 'inci maddesi uyarınca KDK'nın ret kararı ilgilisi tarafından tebliğ alındıktan sonra kaldığı yerden işlemeye devam etmektedir. Başvurunun kabul edilmesi hâlinde ise ilgili merci Kurum'un önerisi üzerine otuz gün içinde herhangi bir işlem tesis etmez veya eylemde bulunmaz ise ${ }^{37}$ durmuş olan dava açma süresi kaldığı yerden işlemeye başlayacaktır (Gümüşkaya, 2016: 288).

36 "Ombudsman kararlarına ciddiyetle uyulması, kurumun saygın, güvenilir ve bağımsız olmasından, ama daha da önemlisi demokratik yapısal bir unsur olarak şeffaflığa dayalı çalışmasından gelir. Bu nedenle, bağlayıcı bir karar mekanizması olmasa dahi, uygulamada idari makamların Ombudsman talep ve tavsiyelerine genellikle uyduğu belirtilmektedir. idarenin, somut olarak vergi idaresinin, Ombudsmanın tavsiyelerine ciddiyetle uyması, uymadığı hallerde bunun haklı gerekçesini açıklaması hukuken değilse bile ahlaki bir sorumluluktur."

37 “ilgili kamu idaresi, KDK'nın önerileri doğrultusunda tesis ettiği işlemi veya KDK'nın önerdiği çözümü uygulanabilir nitelikte görmediği takdirde bunun gerekçesini otuz gün içinde KDK'ya bildirir. Bu tavsiye idareye şikayetle ilgili olarak yerine getirmesi gerekenlerle ilgili olacağı gibi, aynı zamanda bu gibi şikayetlerin yaşanmaması için uygulama ve/veya mevzuat değişikliği de tavsiye edilebilmektedir." 
Aslan, E.F. (2021). "Vergi/Ceza İhbarnamelerine Vergi İnceleme ve/veya Vergi Tekniği Raporlarının Eklenmemesinin İyi İdare ve Dosyaya Giriş Hakları Kapsamında Değerlendirilmesi", International Journal of Public Finance, 6(1), 115-136.

Anayasa mahkemesi ve Danıştay VDDK kararları karşısında KDK'nın aynı konuyla ilgili olup tarafları farklı olan bir uyuşmazlık önüne geldiğinde ne yönde davranacağı, belirtilen kararlar nedeniyle konuyu incelemekten çekinip çekinmeyeceği merak konusu olmakla birlikte kanımızca bu yöntem denemeye değer görülmektedir ${ }^{38}$ (Gümüşkaya, 2016: 288).

\section{Kaynakça}

Aslan, E.F., (2020), "Türkiye Barolar Birliği Reklam Yasağı Yönetmeliği Hakkında Değişiklik Önerileri", Bursa Barosu Dergisi, 112, 73-81, https://www.bursabarosu.org.tr/Home/KbDownload/bursa-barosu-dergisi-sayi$112,(16.02 .2021)$.

Aslan, I.Y., (2017), Rekabet Hukuku, Ekin Basım Yayın Dağıtım, Bursa.

Baykara, B. (2014), “Dayanağı Başka Bir Mükellef Hakkında Yazılan Vergi Tekniği Raporu Olan Vergi Incelemeleri, Vergi Tarhiyatları ve Vergi Davalarının 'Bireysel Başvuru' Hakkı Bakımından İncelenmesi, Vergi Dünyası, 398, 63- 66.

BEDK, (2015), 25 Soruda Bilgi Edinme Hakkı, 1. Basım, Ankara. https://bedk.adalet.gov.tr/Resimler/SayfaDokuman/233202015214925_SORUD A_BILGI_EDINME_HAKKI.pdf, (16.02.2021).

Craig P., (2014), "Article 41 - Right to Good Administration", The EU Charter of Fundamental Rights, Ed: Peers S., Hervey T., Kenner J, Ward A., 1'st Edition, Hart Publishing, $1069-1098$.

Ergin, E. N., (2020), “Anayasa Mahkemesi'nin VTR kararı”, Dünya Gazetesi. https://www.dunya.com/kose-yazisi/anayasa-mahkemesinin-vtr-karari/476562 (16.02.2021).

Gerek Ş. \& Aydın A.R., (2004), “Anayasa'nın 90. Maddesi Değişikliği Karşısında Yasaların Geleceği ve Anayasal Denetim", TBB Dergisi, 55, 226-238, http://tbbdergisi.barobirlik.org.tr/m2004-55-90, (16.02.2021).

Gümüşkaya, G., (2016), "Vergi Ödevlisinin Kamu Denetçiliği Kurumu'na Başvurusu”, iÜHFM, LXXIV (1), 279-304, https://dergipark.org.tr/tr/download/articlefile/292215, (16.02.2021).

Güngördü A. \& Koyuncu T., (2014), Idari Yargı Kararları Işığında Rekabet Kurulu Uygulamaları, Seçkin Yayıncılık, Ankara.

38 "Öte yandan "yargı organlarınca karara bağlanmış uyuşmazlıklara ilişsin" başvuruların kapsam dışında bırakılmasının, yargı kararında yer alan hususlar ile sınırlı olduğu görüşündeyiz. Diğer bir deyişle, Vergi Usul Kanunu'nun 125'inci maddesinde vergi hatalarını düzeltme talepleri bakımından söz konusu olduğu gibi, uyuşmazlığa ilişkin olan ancak yargı organlarınca karara bağlanmamış hususlar KDK'ya başvuru konusu olabilmelidir." 
Aslan, E.F. (2021). "Vergi/Ceza İhbarnamelerine Vergi İnceleme ve/veya Vergi Tekniği Raporlarının Eklenmemesinin İyi İdare ve Dosyaya Giriş Hakları Kapsamında Değerlendirilmesi", International Journal of Public Finance, 6(1), 115-136.

Güzel O. \& Odyakmaz Z., (2017), “ìyi İdare Hakkı”, Akdeniz Üniversitesi Hukuk Fakültesi Dergisi, 7(2), 13-37.

Halimovski E., (2016), “Avrupa Birliği Hukuku'nda İyi Yönetim Hakkı”, Yüksek Lisans Tezi, Dokuz Eylül Üniversitesi Sosyal Bilimler Enstitüsü, İzmir.

Kerse \& Khan N., (2012), EU Antitrust Procedure, 6th Edition, Sweet \& Maxwell.

Korkmaz, C. T., (2020), “AB ve Türk Rekabet Hukukunda Dosyaya Giriş Hakkının Kullanılması”, Rekabet Kurumu Uzmanlık Tezleri Serisi No:177, Ankara.

Policy Department for Budgetary Affairs Directorate General for Internal Policies of the Union (2017), The protection of the procedural rights of persons concerned by OLAF administrative investigations and the admissibility of OLAF Final Reports as criminal evidence, PE 603.790, Brussels. https://www.europarl.europa.eu/ RegData/etudes/IDAN/2017/603790/IPOL_IDA(2017)603790_EN.pdf, (16.02.2021).

Saban, N., (2020), Vergi Hukuku, Beta Yayıncılık, İstanbul.

Şenyüz, D., (2020), Vergi Ceza Hukuku, Ekin Basım Yayın Dağıtım, Bursa.

T.C. AB Bakanlığı, (2013), Avrupa Birliği Müzakere Sürecinde Yargı ve Temel Haklar Faslı, Avukatlar için Yargı ve Temel Haklar Projesi, Ankara, https://www.ab.gov.tr/files/yargivetemelhaklar/yargi_ve_temel_haklar_kitap.pdf, (16.02.2021).

TBMM Tutanak Dergisi, Dönem: 22, Cilt: 48, Yasama Yılı: 2, 83. Birleşim.

Topçu, K. M., (2020), Vergi Hukuku Özelinde Anayasa Mahkemesi'ne Bireysel Başvuru, Seçkin Yayıncılık, Ankara.

Tridimas T., (2017), The General Principles of EU Law, Oxford EU Law Library, 2nd Edition, Oxford University Press.

Turinay, F., (2014), “Avrupa İnsan Hakları Mahkemesi'nin 1996 Tarihli Miailhe v. Fransa Kararı Üzerine Bir İnceleme", Ankara Barosu Dergisi, 2014/3, 333-346, https://dergipark.org.tr/tr/download/article-file/398192, (16.02.2021).

Yaltı, B, (2006), Vergi Yükümlüsünün Hakları, Beta Basım, İstanbul.

Yaltı, B. (2012), "Vergi Uyuşmazlıklarında Yeni Başvuru Yollarının Yargıya Etkisi: Ombudsman Başvurusu ve Bireysel Başvuru", Vergi Sorunları Dergisi, 286, 110-121.

Yaltı, B. (2016), "Vergi İncelemelerinde Dinlenilme Hakkı", Vergi Sorunları Dergisi, 332, 52-57.

Yavaşlar F. B., Güneş K.T., Kapucu G. \& Kocatepe M. (2018), Vergi Hukuku ve Uygulama, Adalet Yayınevi, Ankara.

Anayasa Mahkemesi (AYM) 2016/12198 başvuru numaralı kararı, RG sayı 31200, 29.07.2020. 
Aslan, E.F. (2021). "Vergi/Ceza İhbarnamelerine Vergi İnceleme ve/veya Vergi Tekniği Raporlarının Eklenmemesinin İyi İdare ve Dosyaya Giriş Hakları Kapsamında Değerlendirilmesi", International Journal of Public Finance, 6(1), 115-136.

Ankara 9. İdare Mahkemesi E.2018/1189- K. 2019-2054, 16.10.2019. https://www.rekabet.gov.tr/Safahat?safahatld=63759a65-4cf1-4489-a96f294de23ed9f5, (16.02.2021).

Danıştay 13. Dairesinin 09.09.2013 tarihli E. 2013/1663, K. 2013/2144 sayılı kararı.

Danıştay 3. Dairesi'nin 26.09.2017 tarihli, E. 2016/ 2949, K. 2017/6117 sayılı kararı.

Danıştay 7. Dairesi'nin 25.05.2016 tarihli, E. 2016/2220, K. 2016/4758 sayılı kararı.

Danıştay 9. Dairesinin, 05.11.2009 tarihli, E. 2008/3530, K. 2009/3998 sayılı kararı.

Danıştay VDDK'nın 10.02.2016 tarihli ve E.2016/82, K. 2016/83 sayılı kararı.

Danıştay VDDK'nın 18.06.2014 tarihli ve E.2014/304, K.2014/563 sayılı kararı.

Danıştay Vergi Dava Daireleri Kurulu (VDDK) 03.07.2019 tarihli, E.2019/559, K. 2019/437 sayılı kararı.

ECtHR, Bendenoun v. France, 24.02.1994.

ECtHR, Bruno v Sweden, 28.08.2001.

ECtHR, Editions Periscope v. France, 26.03.1992.

ECtHR, Ferrazzini v. Italy, 12.07.2001.

ECtHR, Funke v. France, 25.02.1993.

ECtHR, J.B. v. Switzerland, 03.08.2001 final.

ECtHR, Janosevic v. Sweden, 23.07.2002.

ECtHR, Miailhe v. France, No.18978/91, 26.9.1996.

ECtHR, Ravon and Others v. France, 21.02.2008.

ECtHR, Terem Ltd, Chechetkin and Olius v. Ukraine, 18.01.2006.

https://rm.coe.int/cmrec-2007-7-of-the-cm-to-ms-on-good-administration/16809f007c, (16.02.2021).

https://www.ab.gov.tr/gumruk-birligi_46234.html, (16.02.2020).

https://www.anayasa.gov.tr/tr/mahkeme/gorev-ve-yetkileri/bireysel-basvuru/, (16.02.2021).

https://www.avrupa.info.tr/tr/avrupa-birligi-temel-haklar-bildirgesi-708, (16.02.2021). https://www.ombudsman.europa.eu/lv/publication/tr/3510_(16.02.2021).

https://www.ombudsman.gov.tr/hakkimizda/index.html, (16.02.2021).

Judgment of the Court (Fifth Chamber) (CJEU), 7 January 2004, Joined Cases C-204/00 P, C-205/00 P, C-211/00 P, C-213/00 P, C-217/00 P and C-219/00 P, Aalborg Portland and others v. Commission.

Judgment of the Court of First Instance (GC) of 17 December 1991, T-7/89, Hercules Chemicals v. Commission. 
Aslan, E.F. (2021). "Vergi/Ceza İhbarnamelerine Vergi İnceleme ve/veya Vergi Tekniği Raporlarının Eklenmemesinin İyi İdare ve Dosyaya Giriş Hakları Kapsamında Değerlendirilmesi", International Journal of Public Finance, 6(1), 115-136.

Judgment of the Court of First Instance (GC) of 18 December 1992, Joined cases T10/92, T-11/92, T-12/92 and T-15/92, Cimenteries CBR SA and others $v$ Commission.

Judgment of the Court of First Instance (GC) of 19 February 1998, T-42/96, Eyckeler and Malt AG v. Commission.

Judgment of the Court of First Instance (GC) of 29 June 1995, T-30/91, Solvay v. Commission.

Judgment of the Court of First Instance (GC) of 29 June 1995, T-36/91, Imperial Chemical Industries plc (ICI) v. Commission.

Rekabet Kurulu'nun 20-18/245-117 sayılı, 02.04.2020 tarihli kararı. https://www.rekabet.gov.tr/Karar?kararld=d949dea3-e393-4761-aab171f61d4c5133, (28.03.2021).

Rekabet Kurulu'nun 20-44/607-268 sayılı, 01.10.2020 tarihli kararı. https://www.rekabet.gov.tr/Karar?kararld=bcdf271b-67f3-46e4-8a782466459092f7, (16.02.2021).

T.C. Kamu Denetçiliği Kurumu'nun 2016/54 şikâyet numaralı, 18.06.2016 tarihli kararı, https://www.ombudsman.gov.tr/contents/files/Bilgi\%20ve\%20Belgelerin\%20Bi Igi\%20Edinme\%20Hakk\%C3\%84\%C2\%B1\%20Kapsam\%C3\%84\%C2\%B1nda\%20K endisine\%20Verilmesi\%20Talebi\%20Hakk\%C3\%84\%C2\%B1nda(1).pdf, (16.02.2021). 